Vol. 4, No. 3, 2019

\title{
COMPARATIVE ANALYSIS OF KEY ASPECTS OF ENVIRONMENTAL POLICY IN THE FIELD OF WATER SECURITY RESOURCES IN DEVELOPING COUNTRIES AND EU
}

\author{
Olena Mitryasova, Yevgen Bezsonov, Victor Smyrnov, Andrii Mats \\ Petro Mohyla Black Sea National University, \\ 10, 68 Desantnykiv Str., Mykolayiv, 54003, Ukraine \\ lesya.solis28@gmail.com,evgbess45@gmail.com,vsmirnov@e-mail.ua,andrejmac3@gmail.com
}

https://doi.org/10.23939/ep2019.03.143

Received: 22.07.2019

(C) Mitryasova O., Bezsonov Y., Smyrnov V., Mats A., 2019

\begin{abstract}
The article analyzes progress in the field of water resources management in the states of the world in the context of the provisions of the concept of sustainable development. Comparison of countries with different levels of development has allowed us to determine key methodological provisions that are proposed to integrate into the environmental policy of water use at the state level in the developing countries. The approach to the determination of the limit indices of the human impact on the environment is proposed.
\end{abstract}

Key words: management of water ecosystems; water resources; environmental security of water resources; environmental policy; sustainable development.

\section{Introduction}

Human health is $80 \%$ dependent on drinking water. In $90 \%$ of the cases, countries with lack of water resources, especially fresh water, lag behind the level of social and economic development. Everything on the planet is directly related to aquatic ecosystems.

The minimum amount of water, according to the UN findings, which must be provided to a person to meet all the annual water needs, is 2000 liters. Considering the growing number of people, in particular the poor, regular growth of industrial production and water consumption in the corresponding technological processes, achieving such values becomes more problematic every year.

Taking into account the given data, there is no doubt that the issue of sustainable use of resources of water ecosystems and maintaining their functional integrity is relevant. In practice the quantity and quality of circumstances that determine the effectiveness of the outcome can be quite significant, depending on the region of the world, but the initial conditions are more or less the same. In this case, it is an issue of the legal provision of the principles of the use of water systems.

At present, uneven implementation of the provisions of sustainable development in the safety of water ecosystems in different countries of the world is traced. The main reason for this, in our opinion, is the imperfection of legal provision of this aspect of nature management. Therefore, there is a need to study the issue of sustainable use of aquatic ecosystems and ensure their safe state in the interstate dimension.

\section{The purpose and objectives of the study}

The purpose of the study is to determine the key principles of environmental safety of aquatic ecosystems in the context of sustainable use of natural resources and socio-economic development.

Achievement of the goal involved the following tasks:

1) to analyze the state of the international practical and legal basis in the field of water environmental safety;

2) to establish the effectiveness of the declared provisions for sustainable use of water in the countries of the world and the current problems in this matter;

3) to substantiate proposals for the improvement of legal and practical environmental protection instruments for aquatic ecosystems in developing countries.

The object of the study is the management of water ecological systems. 
The subject of the research is the provision of ecological safety of aquatic ecosystems in the context of sustainable development.

\section{Results of the study}

The first event in the development of the issue of rational water use, primarily rivers as sources of fresh water, was the United Nations Conference on Water Resources in Mar del Plata (1977, Argentina) which proclaimed the principle of "international cooperation" in the international legislation on the use of water resources and adopted an appropriate Action Plan in this direction. It indicates the internal relation between water management projects and the serious consequences of their implementation which have physical, chemical, biological and socio-economic character. In the field of environmental rehabilitation, the following general objective was set: "to carry out an assessment of the consequences of various types of water use for the environment", "as well as to protect the ecosystem" [1].

All events since 1972 (the Stockholm Environment Conference) have become a kind of "preamble" of 1992 in which the world community identified the basic ways and principles of development in many areas of human activity.

Thus, the fundamental modern document on the use of water resources is the "Agenda for the 21st Century" which was adopted at the 1992 International Conference on the Environment and Development in Rio de Janeiro. Chapter 18 describes the basic principles of the use and management of water resources.

Paragraph 18.2 states that "water is necessary in all spheres of life" and "the overall objective is to ensure an adequate supply of good quality water to the entire population of our planet, while preserving the hydrological, biological and chemical functions of ecosystems, and adjusting human activities taking into account the possibilities of nature" [2].

This document emphasizes that the development and management of water resources must be planned in a comprehensive manner, that is, on a systematic approach, "and should encompass ecological, economic and social factors based on the principle of sustainability" [2, p. 18.16].

Paragraph 18.38 states that one of the main tasks of the international community should be "preservation of the integrity of the ecosystem through the conduct of economic activity based on the principle of protection of aquatic ecosystems, including living resources, and their effective protection against any kind of degradation within the catchment area basin" [2].

Sources [3; 4] state that "water has social, economic and environmental value, so water management should be carried out in the way which ensures the most satisfactory and sustainable combination of these values".

Considering the above, the value of water resources in the context of socio-economic development is beyond doubt. However, the pressing issue is the priority of meeting water needs: world experience demonstrates ambiguity and fundamental differences in the applied approaches.

For example, in source [3], in the second section of the report, human needs for water resources are proved to be a priority.

The report E/C.7/1996/6 [5] emphasizes the fact that one of the tools that can change the balance of relations between human and aquatic ecosystems is to develop better administrative mechanisms that regulate the relationship of human activity and water resources.

Paragraph 58 [5] states that in arid regions, in the case of water shortages, water needs need to be reduced to a minimum and measures should be taken to maximize the efficient use of such resources.

Source [6] draws attention to the fact that "at the global level, the intensity of consumption of renewable resources, in particular fresh water, still exceeds their natural rate of recovery, which, beyond any doubt, is unacceptable and requires improvement in the practice of their use".

Document E / CN.17 / 1997/9 [7] clearly identifies the problem that water consumption is so high that the flow of a number of large rivers decreases downstream, causing water users to feel shortage of water resources. Ecosystems of both rivers and adjacent coastal areas are also affected.

Paragraphs 8, 32, 119, along with the priority of human water needs, emphasize that the consumer approach is unsatisfactory and should be reoriented to ensure the normal functioning of aquatic ecosystems and maintain the necessary hydrological regime of swamps, lakes, rivers and coastal areas, as well as the normal functioning of the natural complex on which human society is built [7].

This idea is supported and proved in several parts of the document. Thus, p. 41 says that the conservation of water resources for the normal functioning of ecosystems is considered as a secondary task compared with the satisfaction of human needs in full. In recent years, however, there has been an understanding of the need to maintain the proper condition of ecosystems, not only in terms of ethical considerations, but also taking into account the practical benefits that a person receives and which are sometimes referred to as the functions of ecosystems. Significant progress has been made in understanding the needs of aquatic ecosystems in freshwater. These needs for water resources are 
recognized as legitimate and force some decision makers to give priority to these "environmental" problems along with the problems of using water resources in economic activity [7].

Great interest was caused by paragraph 70 of the document which actually provides a method for the determination and regulation of anthropogenic pressure on water resources, which undoubtedly requires further practical verification. Thus, it was noted that water pressure could occur if the fresh water consumption exceeds 10 percent of the freshwater volume of renewable water, and it increases significantly when the water consumption exceeds $20 \%$. Any country with the help of dams, reservoirs and water intake structures can take on average no more than one third of the annual flow of their rivers [7].

Source [8], section F, paragraph 39, recommends that all countries at national level should formulate clear guidelines for the management of state bodies in the extreme hydro-meteorological situation and take appropriate measures to preserve the integrity of the water ecosystems. In other words, it is necessary to prioritize the needs of a human and, actually, the components of aquatic ecosystems.

In 1998, the Economic and Social Council considered the document E/CN.17/1998/13 [9], paragraph 5 of which states "the fundamental importance" of "priority attention", which "should be paid to the aspects of the use of water resources" "to meet the goal of truly people-centered sustainable development", that is, the priority of human needs.

The report E/C.14/2000/2 [10] states that the river must be flooded: calls are increasingly being made to ensure the preservation of local values associated with watercourses and water bodies, not only to protect the beauty of nature and biodiversity, but also to guarantee the continuation of their use by humans for various important purposes, which depends on maintaining a certain level of water and annual flood regimes (for example, floodplain forests).

One of the clear rules that should ensure the rational use of natural resources, including water, is "the creation of a stable institutional structure that would not allow spraying efforts and duplication of functions and would be based on a comprehensive but at the same time flexible regulatory framework" [10, p. 32].

In March 2000, the Second World Meeting of Heads of States and Governments on Water Issues took place in Hague. In connection with the excitement because of the global crisis in the field of water resources, two important documents were adopted: "World Water Vision "and" Framework for Action" that were presented by the World Water Commission and the Global Water Partnership. The main purpose of both documents is to justify the need for an integrated approach in the states of the world at all levels of water management [11]. Paragraphs 19 and 25 of the document E/C.14/2000/3 claim the thesis that "all ecosystems are completely dependent on water", therefore, their rational or irrational use may adversely affect the ecosystems.

Paragraph 23 contains the thesis that "water flows fluctuate" according to the laws of nature, and therefore, considering this, a person should develop a mechanism for the use of any resource that would not violate these laws. Back in 1982, the World Charter of Nature affirmed the statement that "nature must be respected and its main processes should not be violated" [12].

When considering the issue of protecting biodiversity and aquatic ecosystems (paragraph 25) attention should be paid to the prevention of both direct and indirect changes in ecosystems. "Water resources are the necessary but not exclusive factor to be taken into account when using and preserving ecosystems," which is the confirmation of compliance with the principles of an integrated (systematic) approach to the use of water resources [12].

The reasons for the slow implementation of the approach are revealed and solutions are suggested in p. 32 [12]. The complex approach is complicated by the large conceptual differences between water management specialists and environmental specialists. This makes the constructive dialogue very difficult. There is often a difference in the scope of the approach: while the first pay attention to the water resources in their function as a component of the landscape, the latter deal with individuals or biomes which need to be protected. Therefore, to start speaking the same language and establish a normal dialogue, the concept needs to be developed by both specialists in the field of water resources and environmental specialists. That is the only possible right way to achieve the inevitable compromise.

The purpose of the current UN policy implemented through UNEP strategies (UNEP/GC/24/4/Add.1) [13], is to promote environmental sustainability in the area of water resource management through integrated ecosystem approaches. One of the main tasks is to "improve the ecosystem justification of water basins management".

The UN resolutions $[14 ; 15]$, the effect of which was scheduled for 2015, the continuation of the humanchoice course on integrated water use was proclaimed, based on the principles enshrined in the UN Basic Conceptual Documents.

Resolution A/RES/67/203 [16], adopted in early 2013, is also intended to support and continue the implementation of the principles of the United Nations 
core documents, including the use of water resources, for the next decade.

The analysis shows that for 40 years humanity has changed approaches to water use, but hasn't changed the priorities.

The main approach is the integrated or ecosystem one which "covers the whole complex of land and aquatic ecosystems, considering the hydrological basin as a unit characterized by the parameters that determine the conditions up and down the flow, including, in particular, specific ecosystems such as forests, land resources, wetlands, urban ecosystems and coastal zones" [13].

However, the main and indisputable priority consumer is a man. This issue becomes especially acute during the period of low water when the question of choice arises: either a person or an ecosystem.

Let's look at the progress in implementation of the provisions declared by the international community in the area of conservation and use of water ecosystems.

\section{European Union}

Nowadays, the European Union is a leader among the regions of the world in the effectiveness of environmental policy implementation (according to the Environmental Efficiency Index - Environmental Performance Index). As of 2018, 20 EU Member States from 28 are among the first thirty countries in the world [17].

Therefore, we cannot ignore the example of European countries in providing sustainable water use.

Adopted in 2000, the Water Framework Directive of the EU defines the basic principles of water resources management and the ways to achieve good water quality and the safe state of rivers and reservoirs. It has become a guideline for setting the goals of water conservation in this century.

The directive aims at protection of the qualitative and quantitative characteristics of water bodies in the EU and establishes the basic principles of the European Union's restorative water policy [18].

Having read the text of the document, it is obvious that the provisions of the UN documents are the basis of the EU's water policy.

The first paragraph of this document states that "water is an inheritance that needs to be protected, defended and treated accordingly".

The most interesting thing is written in p. 32 . Human interests can be the priority in providing water: there may be grounds for exceptions to the requirements for preventing further deterioration or achieving a good state in specific conditions where non-compliance with such requirements is the result of unforeseen or exceptional circumstances, especially floods or droughts, or because of the priority public interest, or new modifications in the physical characteristics of a surface water object, or changes in the level of water in underground water bodies, provided that all practical steps are taken in order to reduce the negative impact on the water body [18].

We find some contradiction between the two points which is regulated in Article 4, paragraph 5 of the directive: "Member States may strive to achieve less stringent environmental objectives for specific water bodies, provided that the ecological and socio-economic needs, which such human activities serve, cannot be achieved by other means".

Considering the foregoing, the European approach to water use can indeed be considered exemplary: first, the needs of the ecosystem in water, but only then a man.

\section{Countries of the post-Soviet space}

The main document regulating water use in Ukraine is the Water Code of Ukraine (WCU) [19]. Articles 45 and 55 define the right of priority satisfaction of drinking and household needs in the process of water use.

Article 49 deals with the mechanism of action in case of low water in the river: "in case of low water, the limits of special water use may be reduced by specially authorized state bodies without adjusting the permission for special water use", with the mandatory implementation of the provisions of Articles 45 and 55.

There is nothing in the Water Code about the interests of hydrobionts in case of low water crisis.

Article 97 regulates the need for the protection of fish, aquatic animals and plants in the context of "placement, design, construction, reconstruction and commissioning of enterprises, structures and other objects at fishery water objects". That is, this article is valid only for one type of water management.

In addition, the concept of "aquatic ecosystem", which has become widespread in international law, academic and scientific literature, is used in the document only once, in Article 108 in the context of the occurrence of water accidents, "which may have a harmful effect on the health of people and the state of water ecosystems", without any explanation as to the content of the latter.

One huge milestone of the Ukrainian legislation should be emphasized - it does not operate the definitions such as "ecological system", "ecosystem services", etc.. In the context of sustainable development, it is a huge regress.

Article 3 states that the water legislation of the Russian Federation is based on the principles: "2) the priority of the protection of water objects (a system of measures aimed at the conservation and restoration of 
water objects (Article 1)) before using them. The use of water bodies should not have any negative impact on the environment" and "the priority of using water objects for the purposes of drinking and household water supply ahead of other purposes of their use. Their use for other purposes is only possible if there are sufficient water resources".

Article 46 of the Water Code of the Russian Federation states that industrial water users should be guided by the priority of drinking and household water supply and "with observance of the requirements of rational use and protection of water objects" [20].

In general, the Water Code of the Russian Federation in the subject under study is more perfect, since the interests of people and aquatic organisms are the highest in the water legislation of the state, although the priority between them is not clearly defined.

Articles 5, 33, 48, and 50 of the Water Code of the Republic of Belarus establish the priority in meeting the needs of the population for drinking and household needs [21]. The interests of hydrobionts are enshrined in Article 69 in the same way as in Article 95 of the WCU [19].

Article 1 of the Water Code of the Republic of Moldova contains the provision that one of its objectives is "improvement of the status of aquatic ecosystems and their preservation for present and future generations" based on "sustainable, balanced and equitable water use", "phased and systematic transition of water protection and water management to European standards" [22]. In Article 6, the principle of "participation of water users" enshrines the right of citizens to submit proposals on the use and protection of water to environmental protection bodies.

Article 24 confirms the priority of meeting the needs of the population for water. The section of the Law on Drought and Flood Management, based on the principle of situational dynamism, is interesting in its content.

Articles 8 and 104 of the Water Code of the Republic of Kazakhstan mention the priority of drinking and household water supply.

Article 34, as well as the above-mentioned Code, provides the interpretation of "sustainable water use", introduces the notion of the principle of public administration in the field of water resources, "preservation of ecological sustainability of the environment", and article 10 - the notion of "natural aquatic ecological system", which was not found in either of the above-mentioned Codes [23].

Article 14 of the Water Code of the Republic of Tajikistan states that the commissioning of any objects that affect the state of water "must ensure the rational use of water in accordance with the requirements of environmental safety and health care, the priority of meeting the drinking and household needs of the population; also" depending on the natural and economic conditions, measures to ensure the protection of fish, other aquatic animals and plants and the conditions for their reproduction "should be carried out in a timely manner" [24].

This document, unlike some of the studied above, provides the protection of water biota for all water reservoirs regardless of water management and not only for fisheries.

The priority of human needs is also enshrined in a separate Article 30, as well as in Articles 44 and 81.

Protection of hydrobionts' interests is also set forth in Article 17 which states that "the commissioning of water management facilities is forbidden if their projects do not provide compensation for damage to fish stocks, other aquatic animals and plants".

Consequently, the level of development of sustainable administrative approaches to the management of water ecosystems is significantly different.

\section{Water legislation of the world countries}

It is valuable and interesting to compare the experience of water legislation in the world countries of different continents: one or two countries from each continent. This will allow us to evaluate the community of people's opinions on a global scale and, to some extent, commitment to the principles of sustainable development.

Water legislation of the People's Republic of China (PRC) is presented by the Water Code of the People's Republic of China [25].

Article 21 stipulates that "when developing and using water resources, the needs for water supply of the inhabitants of cities and rural areas should be met first of all, and the needs of industry and agriculture, the environment and navigation must be fully taken into account. In the areas with limited water resources, the environmental needs for water must be taken into account when developing and using water resources. Human needs for water are the priority, but with regard to the environment and industry, it cannot be said unequivocally.

The Australian Water Management Act is the Water Act 2007 adopted in 2007 [26].

In this document, paragraph 3 of the Preamble states that one of the objectives of the Law is the implementation of the provisions of international agreements on the use of water resources in order to optimize the economic, social and environmental development outcomes. The term "Terminology" introduces and explains the concept of "ecologically safe water intake level", which means the amount of water 
that can be taken from the water object without endangering the properties of the ecosystem, its components, or adversely affecting its functionality [26].

The document also states that "if there is a risk of causing significant or irreversible damage to the environment, the lack of full scientific certainty should not be used as a reason for delaying the adoption of measures to prevent deterioration of the environment".

Section 2A "Critical human water needs" defines human needs for water as the minimum amount of water that can only be taken from a water object and which will allow people to meet their needs. Human needs for water are the highest priority.

However, the principle requires fairly strict conditions (Section 5, paragraph 86A). The natural diversity of habitats and biota within the river channel, coastal zones and floodplains; natural connections between the river and the floodplain; natural metabolism of aquatic ecosystems should be preserved or enlarged, as well as the elements of the natural regime of the river flow should be maintained or expanded as much as possible to preserve the niche for native (aboriginal) species and support the natural functions of the river [26].

Australian water legislation is clearly formulated and despite the fact that priority is still given to human needs, the interests of hydrobionts and aquatic ecosystems are fixed at a very high level: "the environment is seen there as a" legitimate "water user".

In the United States, water use is regulated by Chapter 16 of the United States Code of Conduct (US Code - Title 16 Conservation) [27].

Paragraph 460o- 4, subparagraph 1, stipulate the provision that human needs are of primary importance in providing water. Interests of hydrobionts are fixed at the level of principles of environmental protection and rational use of natural resources.

In Brazil, the primary focus on providing water is also provided to the population [28].

In the countries of Africa, with the help of the UN, a process of reorientation of priority water needs from agriculture to the inhabitants' needs is taking place [7, p. 107]. For example, in Zimbabwe's water legislation amendments have been made to strengthen the priority of water supply for urban residents [5, p. 45].

In India there are clearly established principles of taking account of environmental issues when designing river valley development projects. Section 8 of the Water Development Policy provides that water distribution is a national priority (p. 44 [5]).

Considering the above, it is obvious that human needs for water are in most cases recognized as priority in relation to aquatic ecosystems.

Therefore, perhaps, the conclusion of Human Development Report is quite natural.It states that many countries, especially those with a high index of human development, are developing nowadays in unsustainable way. For example, according to available statistics, in 82 of 140 countries such index of development as an "ecological footprint" exceeds the global recovery potential of the Earth.

\section{Discussion of results}

The process of human transformation of the environment according to one's own needs to a certain level can be justified by the examples from nature. For example, termites erect huge towers, in which they maintain optimum humidity necessary for life, and grow nutrition. Ants and bees act in the same way. However, such transformation of a small fraction of the earth's surface or space does not violate their integrity and, moreover, the functional capabilities of the ecosystem.

The incorrectness of anthropocentric approach when a person is the center of care, in accordance with the provisions of the UN, is as follows. Fig. 1.

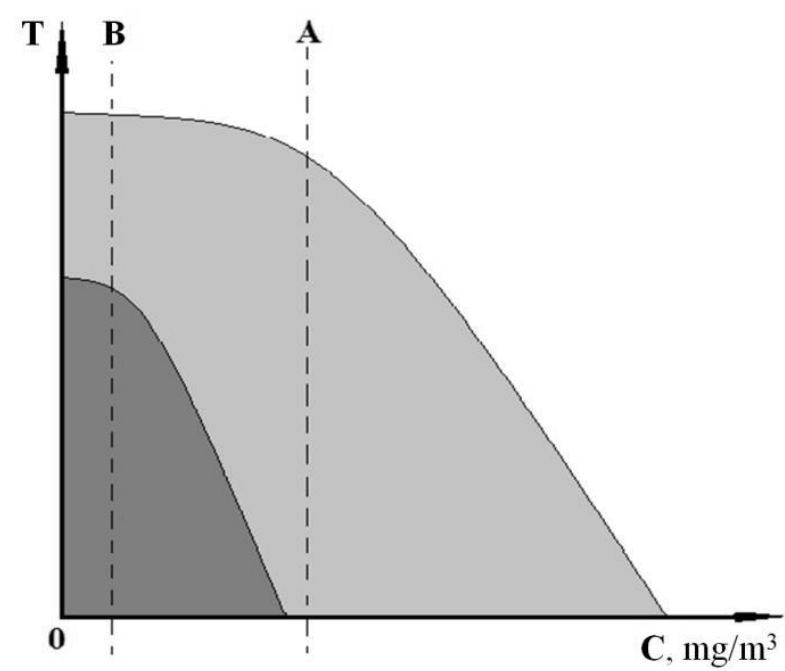

Fig. 1. Tolerance of a man (A) and a bee (B) to air pollution

A man is one of the species whose adaptive properties of an organism to the environment are among the most developed. In other words, the human tolerance zone to the action of any negative environmental factor (both natural and artificial) is greater in relation to most other living organisms. Based on this, while option A of atmospheric air is permissible for a man, option B - only for certain insects, such as bees (it is known that since 2011 the UN has stated the decline of bees' population in North America and Europe). According to the law of nature, bees must be the limiting factor of anthropogenic pressure on atmospheric air in this case. However, in practice, it is quite different. In this case (Fig. 1), the use of the law of tolerance allows determining the limits of safe concentrations of harmful substances in the 
environment by combining the ecological characteristics of humans and vulnerable organisms,

Therefore, it is fair to say that at the current stage of development of most countries of the world the synergy of the above-mentioned aspects does not significantly allow to prevent and solve environmental problems in social ecosystems of different levels.

\section{Conclusions}

The level of water consumption from rivers is extremely high, which leads to the shortage of water resources downstream for both natural ecosystems and coastal areas. Changing natural hydrological regimes by human activity will always cause the emergence of environmental and economic external factors in downstream areas. Therefore, continuous monitoring of the status of aquatic ecosystems is crucial for social and economic planning at the state and regional levels in any country of the world.

The European Union, Australia, Moldova and Kazakhstan have officially endorsed the legitimacy of prioritizing the needs of aquatic ecosystems for fresh water. The growing shortage of freshwater resources will encourage other countries of the world to focus on the environmental problems of water resources in the near future.

It has been revealed that most post-Soviet countries do not use the concepts of "ecological system" and "ecosystem services" in their own legislative framework which nowadays are an integral part of environmental policy and legislation of developed countries. The use of the notion of "water objects" which is typical, for example, for Ukraine, leads to the transfer of the process of water resources management to the plane of anthropocentrism, consumer nature use. Despite declaring the equality of social, economic and ecological components of development, most of the investigated legislative documents of the world countries declare people' needs for water to be the highest priority.

The basic principles for providing environmental safety of aquatic ecosystems are as follows:

- a water object (surface or underground) is a complex, functionally integrated and self-regulated environmental system. It cannot be considered as a volume with a resource for biological and household human needs;

- the priority in water use should be given to the living components which exist in it and ensure its functional integrity;

- any aquatic ecosystem must be economically valued not only from the perspective of the available water resources, but also taking into account other ecosystem services, especially the diversity of its biotic components. Only in this way, humanity (the local population) can understand the value of water ecosystems.

In case of implementation in domestic legislation, all these principles and the approach outlined in the work will allow achieving progress in the field of environmental safety of aquatic ecosystems and sustainable social and economic development.

\section{Acknowledgements}

We would like to thank the Erasmus+ Programme of the European Union for the support in the research work in the framework of the Jean Monnet project.

\section{References}

[1] Doklad konferencii organizacii obedinennyx nacij po vodnym resursam, mar-del-plata. 14-25 marta 1977 goda (izdanie organizacii obedinennyx nacij, v prodazhe pod No r.77.ii.a.12), chast pervaya, glava i, razdel s, punkt 35. [Electronic resource]. Access mode: www.un.org.

[2] Povestka dnya na XXI vek / Konferenciej OON po okruzhayushhej srede i razvitiyu, Rio-de-Zhanejro, 314 iyunya 1992 goda. [Electronic resource]. Access mode: http://www.un.org/ru/documents/decl_conv/ conventions/agenda21.

[3] Obzor progressa $\mathrm{v}$ reshenii voprosov, svyazannyx $\mathrm{s}$ vodnymi resursami: rassmotrenie institucionnyx i pravovyx voprosov upravleniya vodnymi resursami. OON. Ekonomicheskij i Socialnyj Sovet. Tretya sessiya (6-17 maya, 1996 goda). [Electronic resource]. Access mode: https://documents-dds-ny.un.org/doc/UNDOC/ GEN/N96/071/79/PDF/N9607179.pdf.

[4] Protokol po problemam vody i zdorovya k Konvencii po oxrane i ispolzovaniyu transgranichnyx vodotokov i mezhdunarodnyx ozer 1992 roku. Ekonomicheskij i Socialnyj Sovet OON. Vtoraya sessiya, 23-25 marta 2000 goda. [Electronic resource]. Access mode: http://www.un.org/ru/documents/decl_conv/convention s/water_protection.shtml.

[5] Formiruyushhie voprosy upravleniya vodnymi resursami i strategii i politika, kotorye mezhdenarodnomu soobshhestvu sleduet rassmotret $\mathrm{v}$ svyazi s nimi / Mezhsessionnyj direktivnyj dokument Komiteta po prirodnym resursam po formiruyushhimsya voprosam upravleniya vodnymi resursami i sootvetstvuyushhim strategiyam i politike. Ekonomicheskij i Socialnyj Sovet. Tretya sessiya, 6-17 maya 1996 goda. [Electronic resource]. Access mode: https://documents-dds-ny.un. org/doc/UNDOC/GEN/N96/075/00/img/N9607500.pdf.

[6] Programma dejstvij po dalnejshemu osushhestvleniyu "Povestki dnya na XXI vek", prinyataya generalnoj assambleej na ee devyatnadcatoj specialnoj sessii (23-28 iyunya 1997 goda). [Electronic resource]. Access mode: https://documents-dds-ny.un.org/doc/ UNDOC/GEN/N97/774/75/PDF/N9777475.pdf. 
[7] Vseobemlyushhaya ocenka mirovyx resursov presnyx vod. Doklad Generalnogo Sekretarya OON. Ekonomicheskij i Socialnyj Sovet. Komissiya po ustojchivomu razvitiyu. Pyataya sessiya (7-27 aprelya 1997 goda). [Electronic resource]. Access mode: http://repository.un.org/bitstream/handle/11176/214573 /E_CN.17_1997_9-RU.pdf?sequence=5\&isAllowed=y.

[8] Strategicheskie podxody k racionalnomu ispolzovaniyu resursov presnoj vody. Doklad generalnogo sekretarya. OON. Ekonomicheskij i Socialnyj Sovet. Komissiya po ustojchivomu razvitiyu. Shestaya sessiya (20 aprelya 1 maya 1998 goda). [Electronic resource]. Access mode: https://www.preventionweb.net/files/resolutions/ N9803119.pdf.

[9] Doklad mezhsessionnoj specialnoj rabochej gruppy po strategicheskim podxodam $\mathrm{k}$ racionalnomu ispolzovaniyu resursov presnoj vody / Komissiya po ustojchivomu razvitiyu, shestaya sessiya, 20 aprelya 1 maya 1998 goda. [Electronic resource]. Access mode: https://documents-dds-ny.un.org/doc/UNDOC/ GEN/N98/092/73/pdf.

[10] Voprosy, kasayushhiesya territorialnogo planirovaniya (vklyuchaya mineralnye resursy) i vodnyx resursov. Doklad Generalnogo sekretarya. Komitet po energeticheskim i prirodnym resursam $\mathrm{v}$ celyax razvitiya. Vtoraya sessiya (14-25 avgusta 2000 goda). [Electronic resource]. Access mode: www.un.org.

[11] Osnovnye voprosy, svyazannye s kompleksnym planirovaniem i racionalnym ispolzovaniem zemelnyx resursov, ekosistemami i osvoeniem, ispolzovaniem i zashhitoj zapasov presnoj vody s udeleniem osobogo vnimaniya faktoru kolichestva i kachestva vodnyx resursov, sovmestno ispolzuemyx pribrezhnymi gosudarstvami. Kompleksnoe racionalnoe ispolzovanie vodnyx resursov - primirenie interesov vodopolzovaniya, zemlepolzovaniya i ekosistem / Komitet po energeticheskim i prirodnym resursam v celyax razvitiya. Ekonomicheskij i Socialnyj Sovet. Vtoraya sessiya, 14-25 avgusta 2000 goda. mezhsessionnyj tematicheskij dokument. [Electronic resource]. Access mode: http://repository.un.org/ handle/11176/231720.

[12] Vsemirnaya xartiya prirody / OON / Rezolyuciya 37/7 Generalnoj Assamblei ot 28 oktyabrya 1982 goda. [Electronic resource]. Access mode: http://www.un. org/ru/documents/decl_conv/conventions/charter_for_n ature.shtml.

[13] Obnovlennaya politika i strategiya Programmy Organizacii Obedinennyx Nacij po okruzhayushhej srede v oblasti vodnyx resursov. Doklad Direktoraispolnitelya. Sovet upravlyayushhix Programmy Organizacii Obedinennyx Nacij po Okruzhayushhej Srede. Dvadcataya sessiya (5-9 fevralya 2007 goda). globalnyj forum po okruzhayushhej srede na urovne ministrov. [Electronic resource]. Access mode: https://documents-dds-ny.un.org/doc/UNDOC/GEN/ K06/536/55/pdf/K0653655.pdf.

[14] Rezolyuciya "Mezhdunarodnoe desyatiletie dejstvij "Voda dlya Zhizni", 2005-2015 gody". Generalnaya
Assambleya OON. - 58 sessiya, 9 fevralya 2004 goda. [Electronic resource]. Access mode: www.un.org.

[15] Rezolyuciya "Vikonannya Poryadku Dnnogo na XXI stolittya, Programi dij $\mathrm{z}$ podalshogo vikonannya Poryadku dennogo na xxi stolittya i rishen Vsesvitnoï Zustrichi na najvishhomu rivni zi stalogo rozvitku i Konferenciï Organizaciï Ob'€dnanyx nacij zi stalogo rozvitku". OON. Generalna Asambleya. Shistdesyat soma sesiya (27 lyutogo 2013 roku). [Electronic resource]. Access mode:www.un.org.

[16] 2018 EPI Results. [Electronic resource]. Access mode: https://epi.envirocenter.yale.edu/epi-topline? country=\&order=field_epi_rank_new\&sort=asc.

[17] Directive 2000/60/EC of the European Parliament and of the Council of 23 October 2000 establishing a framework for Community action in the field of water policy. [Electronic resource]. Access mode: https://eurlex.europa.eu/legalcontent/EN/TXT/?uri=CELEX:02000L0060-20141120.

[18] Vodnij kodeks Ukraïni vid 6 chervnya 1995 roku (zi zminami vid 02.07.2013). [Electronic resource]. Access mode: http://zakon4.rada.gov.ua/.

[19] Vodnyj kodeks Rossijskoj Federacii ot 03.06.2006 n 74-FZ (red. ot 03.08.2018) (s izm. i dop., vstup. v silu s 01.01.2019). [Electronic resource]. Access mode: http://www.consultant.ru/document/cons_doc_LAW_6 0683/.

[20] Vodnyj kodeks Respubliki Belarus ot 30 aprelya 2014 g. No. 149-z. [Electronic resource]. Access mode: http://kodeksy.by/vodnyy-kodeks.

[21] Zakon o vode Respubliki Moldova. [Electronic resource]. Access mode: http://lex.justice.md/ $\mathrm{ru} / 342978 /$.

[22] Vodnyj kodeks Respubliki Kazaxstan ot 9 iyulya 2003 goda № 481-II (s izmeneniyami i dopolneniyami po sostoyaniyu na 28.12.2018 g.). [Electronic resource]. Access mode: https://online.zakon.kz/Document/ ?doc_id=1042116.

[23] Vodnyj kodeks Respubliki Tadzhikistan. [Electronic resource]. Access mode: http://www.obinushoki.tj/ wpcontent/uploads/2016/02/vk_rt.pdf.

[24] Zakon KNR ob oxrane vodnyx resursov. [Electronic resource]. Access mode: https://asia-business.ru/ law/law2/certificate/waterresources/.

[25] Water Act 2007. [Electronic resource]. Access mode: http://www.environment.gov.au/topics/aboutus/legislation.

[26] United States Code. [Electronic resource]. Access mode: http://www.gpo.gov.

[27] Voprosy, kasayushhiesya territorialnogo planirovaniya (vklyuchaya mineralnye resursy) i vodnyx resursov. Doklad Generalnogo sekretarya. Komitet po energeticheskim i prirodnym resursam $\mathrm{V}$ celyax razvitiya. Vtoraya sessiya (14-25 avgusta 2000 goda). [Electronic resource]. Access mode: www.un.org.

[28] Human Development Report 2014: Sustaining Human Progress: Reducing Vulnerabilities and Building Resilience [Text] / United Nation Development Programme. - USA, New York, 2014. - ISBN 978-921-126368-8, eISBN 978-92-1-056659-9. 